this complication still occurs and prompt, skilled treatment is necessary if the mortality is to be reduced.

JOHN S M ZORAB

Consultant Anaesthetist,

Frenchay Hospital,

Bristol BS16 1LE

${ }^{1}$ Mendelson CL. The aspiration of stomach contents into the lungs during obstetric anesthesia. Am f Obstet Gynecol 1946;52:191-205.

${ }^{2}$ Edwards G, Morton HJV, Pask EA, Wylie WD. Deaths associated with anaesthesia. A report on 1000 cases. Anaesthesia 1956;11:194-220.

${ }^{3}$ Cameron JL, Mitchell WH, Zuidema GD. Aspiration pneumonia. Clinical outcome following documented aspiration. Arch Surg 1973; $106: 49-52$.

4 Lewinski A. Evaluation of methods employed in the treatment of the chemical pneumonitis of aspiration. Anesthesiology $1965 ; 26: 37-44$

${ }^{5}$ Chapman RL Jr, Downs JB, Modell JH, Hood JI. The ineffectiveness of steroid therapy in treating aspiration of hydrochloric acid. Arch Surg $1974 ; 108: 858-61$.

6 Downs JB, Chapman RL Jr, Modell JH, Hood CI. An evaluation of steroid therapy in aspiration pneumonitis. Anesthesiology $1974 ; 40: 129-35$.

${ }^{7}$ Glauser FL, Millen JE, Falls R. Increased alveolar epithelial permeability with acid aspiration: the effects of high-dose steroids. Am Rev Respir Dis $1979 ; 120: 1119-23$

${ }^{8}$ Lowrey LD, Anderson M, Calhoun J, Edmonds H, Flint LM. Failure of corticosteroid therapy for experimental acid aspiration. $\mathcal{F}$ Surg Res $1982 ; 32: 168-72$.

${ }^{9}$ Peitzman AB, Shires GT III, Illner H, Shires GT. The effect of intravenous steroids on alveolar-capillary membrane permeability in pulmonary acid injury. $\mathcal{f}$ Trauma $1982 ; 22: 347-52$.

10 Toung TJK, Bordos D, Benson DW, et al. Aspiration pneumonia: experimental evaluation of albumin and steroid therapy. Ann Surg $1976 ; 83: 179-84$

11 Warriner CB, Brooks L, Pare PD. The effect of inhalation of nebulized steroid on the acid aspiration syndrome. Can Anaesth Soc $\mathcal{F} 1981 ; 28$ : 436-41.

12 Toung TJ, Cameron JL, Kimura T, Permutt S. Aspiration pneumoniatreatment with osmotically active agents. Surgery $1981 ; 89: 588-93$.

13 Broe PJ, Toung TJK, Cameron JL. Aspiration pneumonia. Surg Clin North Am 1980;60:1551-64.

14 Cameron JL, Sebor J, Anderson RP, Zuidema GD. Results of treatment by positive-pressure ventilation in dogs. $\mathcal{F}$ Surg Res 1968;8:447-57.

15 Peitzman AB, Shires GT, Illner H, Shires GT. Pulmonary acid injury; effects of positive end-expiratory pressure and crystalloid vs colloid fluid resuscitation. Arch Surg 1982;117:662-8.

16 Toung T, Saharia P, Permutt S, Zuidema GD, Cameron JL. Aspiration pneumonia; beneficial and harmful effects of positive end-expiratory pressure. Surgery $1977 ; 82: 279-83$.

17 Broe PJ, Toung TJK, Permutt S, Cameron JL. Aspiration pneumonia; treatment with pulmonary vasodilators. Surgery 1983;94:95-9.

\section{Imaging procedures to diagnose gall bladder disease}

The growing range of radiological techniques has increased rather than reduced the difficulty of selecting appropriate diagnostic tests, and nowhere is this better shown than in the investigation of gall stone disease. In a recent review, however, Frommhold and Wolf declared that "Today, it must be considered accepted practice wherever biliary tree pathology is suspected, that the first differential diagnostic procedure to follow the taking of the case history, physical examination, and laboratory examinations, is ultrasonography." The technique is safe, free from the hazard of radiation, rapidly performed, pleasant for the patient, and inexpensive. To compare ultrasonography with the other techniques available I propose to look at the use of radiological techniques in the diagnosis of two common disorders associated with stones in the gall bladder: chronic cholecystitis and acute cholecystitis. (I have excluded the other conditions associated with gall stonesextrahepatic obstructive (cholestatic) jaundice and retained stones after cholecystectomy-for these entail evaluation of invasive techniques for showing stones in the common bile duct which are largely irrelevant to the diagnosis of stones in the gall bladder.)

Chronic cholecystitis is usually associated with stones in the gall bladder, and these may be diagnosed by ultrasound with an accuracy of between $90 \%$ and $99^{\circ}{ }_{0} .{ }^{1-3}$ Gall stones are recognised as echogenic foci within the gall bladder; they have a posterior acoustic shadow and move with gravity. Grey scale ultrasonography is being superseded by high resolution dynamic or real time scanners, which are flexible, rapid, and enable movement to be seen. Scanning takes about 5-10 minutes compared with 20-40 minutes with the older machines. The accuracy of ultrasound in the diagnosis of gall stones compares favourably with oral cholecystography ${ }^{45}$ and has the advantage of allowing a more accurate assessment of the thickness of the gall bladder wall and the calibre of the hepatic and common bile ducts. Although the accuracy of a technically satisfactory oral cholecystogram is high, ${ }^{4}{ }^{6}$ many apparently normal gall bladders are inadequately opacified by a single dose of contrast, ${ }^{78}$ so that either tomographic studies ${ }^{9}$ or a second cholecystogram is necessary. ${ }^{710}$

Ultrasonography has considerable advantages, but there are drawbacks: the technique requires a skilled operator, and it may fail to locate the gall bladder-especially if there is overlying gas, although this problem is largely avoided by using real time ultrasonography. ${ }^{4}$

If gall stones are to be dissolved successfully, it is essential to diagnose their presence and nature accurately. Treatment is indicated only if the stones are made of cholesterol, and stopped when the gall bladder is shown to be free of stones. Current convention regards gall stones that appear radiolucent on oral cholecystography as being made of cholesterol, when medical treatment may be offered. Ultrasonography is less accurate than cholecystography for identifying gall stones containing calcium and differentiating between cholesterol and pigment stones. Stones that float in the cholecystogram are almost certainly of cholesterol, though less than one third of these are buoyant. ${ }^{11}$ Somerville and colleagues, however, question the use of cholecystography to assess the dissolution of gall stones and claim that small stones may be missed; in their study of 14 patients with normal cholecystograms, six had gall stones detected by ultrasonography. ${ }^{12}$ The British Gall Stone Study Group has shown that both techniques have limitations in the detection of recurrence of stone. ${ }^{13}$ Hence probably the assessment of response to treatment and the detection of recurrent stones still require an oral cholecystogram. ${ }^{14}$

De Lacey and colleagues examined 500 patients by both techniques and suggest that all patients with non-acute gall bladder symptoms should have both an oral cholecystogram and an ultrasound examination. Those patients with a normal ultrasonic scan should then have compression fluoroscopic cholecystography." These two techniques detect gall stones with similar accuracy, but ultrasonography is less reliable in the diagnosis of acalculous adenomyomatosis and polypsalthough the clinical importance of adenomyomatosis is uncertain. It is present in some $40-80^{\circ}$, of gall bladders removed at surgery, but only $5_{\%}$ of oral cholecystograms show the characteristic features of the condition-intramural diverticula, which indicate Rokitansky-Aschoff sinuses. ${ }^{1.5}$ Furthermore, the management is controversial, for many surgeons dislike removing a gall bladder which does not contain stones as an elective procedure, because complaints are common after cholecystectomy.

Cholelithiasis accounts for more than $85^{\circ}$; of all biliary tract disease, and most clinicians take steps to exclude stones before considering an alternative diagnosis." $\mathrm{A}$ "belt and braces" approach does seem unnecessary, and de Lacey's 
proposal needs further evaluation because, although the extra expense of performing both techniques on a single patient may be small, the number of patients with suspected gall bladder disease who pass through every radiological department is large and so the overall cost to the health service may be considerable.

There should be less difficulty in recommending the best method to confirm a clinical diagnosis of acute cholecystitis, since there has been wide acclaim for cholescintigraphy using ${ }^{99 \mathrm{~m}} \mathrm{Tc}$ labelled derivatives of iminodiacetic acid (HIDA, PIPIDA) and pyridoxylidene glutamate. This new technique is simple and has a specificity approaching $100^{\prime \prime}{ }_{0} .^{17-19} \mathrm{It}$ depends on the fact that acute cholecystitis occurs in association with a blocked cystic duct, and the criteria for a positive scan are non-visualisation of the gall bladder but prompt opacification of the bile duct and duodenum. Prompt and accurate diagnosis is important, because current practice favours early cholecystectomy. ${ }^{20}$ Enthusiasm for the radionuclides is not universal, ${ }^{1}$ however, and false positive scans occur in alcoholic liver disease and in patients receiving parenteral nutrition. ${ }^{21}$ Nevertheless, cholescintigraphy is better than ultrasonography, for although the ultrasonogram may show gall stones and a thickered gall bladder wall it is less accurate than the cholescintigram. ${ }^{321} 22$ Radionuclide imaging is unsatisfactory for the diagnosis of chronic cholecystitis and cholelithiasis. Computed tomography has not been mentioned among the imaging options, for in Britain the procedure is expensive and not widely available. By contrast with its potential for the diagnosis of stones in the bile duct, it has no advantage over oral cholecystography, ultrasonography, or radionuclide imaging as the initial technique for the diagnosis of either acute or chronic gall bladder disease. ${ }^{1222-24}$

In conclusion, the choice of which imaging technique to use to support a diagnosis of gall bladder disease is not always simple and requires an accurate assessment of the patient as well as familiarity with the various radiological skills.

\section{IAN A D BOUCHIER}

Professor of Medicine,

University of Dundee,

Ninewells Hospital and Medical School,

Dundee DD1 9SY

' Frommhold W, Wolf F. Radiological and radionuclide methods for the diagnosis of biliary disorders. Clin Gastroenterol 1983;12:65-100.

${ }^{2}$ Ferrucci JT Jr. Body ultrasonography. N Engl f Med 1979;300:590-602.

${ }^{3}$ Cooperberg PL, Burhenne JH. Real-time ultrasonography. Diagnostic technique of choice in calculous gallbladder disease. $N$ Engl $\mathcal{f} \mathrm{Med}$ 1980;302:1277-9.

- Krook PM, Allen FH, Bush WH Jr, Malmer G, MacLean MD. Comparison of real-time cholecystosonography and oral cholecystography. Radiology $1980 ; 135: 145-8$.

'De Lacey G, Gajjar B, Twomey B, Levi J, Cox AG. Should cholecystography or ultrasound be the primary investigation for gall bladder disease? Lancet $1984 ; \mathrm{i}: 205-7$.

' Cooley RN, Donner MW. The diagnostic accuracy of radiologic studies of the biliary tract, small intestine and colon. Am f Med $S_{c i} 1963 ; 246$ : 610-38.

' Mujahed Z, Evans JA, Whalen JP. The nonopacified gallbladder on oral cholecystography. Radiology $1974 ; 112: 1-3$.

* Loeb PM, Berk RN, Janes JO, Perkin L, Moore J. The effect of fasting on gallbladder opacification during oral cholecystography: a controlled study in normal volunteers. Radiology 1978;126:395-401.

"Melnick GS, Lo Curcio SB. The "nonvisualized" gallbladder. A tomographic re-evaluation. Radiology 1973;108:513-5.

${ }^{10}$ Berk RN, Loeb PM, Goldberger LE, Sokoloff J. Oral cholecystography with iopanoic acid. $N$ Engl F Med $1974 ; 290: 204-10$.

$"$ Dolgin SM, Schwartz JS, Kressel HY, et al. Identification of patients with cholesterol or pigment gallstones by discriminant analysis of radiographic features. $N$ Engl 7 Med $1981 ; 304: 808-11$.

12 Somerville KW, Rose DH, Bell GD, Ellis WR, Knapp DR. Gall stone dissolution and recurrence: are we being misled ? Br Med $\mathcal{F} 1982 ; 284$ : 1295-7.

${ }^{13}$ Gleeson D, Ruppin DC, Dowling RH, British Gall Stone Study Group.
British Gall-stone Study Group (BGSG) post-dissolution trial: interim report on overall recurrence rates and discrepancies between ultrasonography (US) and oral cholecystography (OCG). Gut 1983;24: A 1006.

${ }^{14}$ Dowling RH. Cholelithiasis: medical treatment. Clin Gastroenterol 1983; 12:125-78.

15. Raghavendra BN, Subramanyam BR, Balthazar EJ, Horii SC, Megibow AJ, Hilton S. Sonography of adenomyomatosis of the gallbladder: radiologic-pathologic correlation. Radiology 1983;146:747-52.

${ }^{16}$ Rigo M, Mosimann R, Ryncki P, Saegesser F. Pathologic chirurgicale de la vésicule et des voies bilaires. Helv Chir Acta 1974;41:533-6.

17 Down RHL, Goldin A, Arnold J, Watts JMcK, Benness G. Comparison of accuracy of $99 \mathrm{~m}$ Tc-pyridoxylidene glutamate scanning with oral cholecystography and ultrasonography in diagnosis of acute cholecystitis. Lancet 1979; ii:1094-7.

1* Weissmann HS, Frank MS, Bernstein LH, Freeman LM. Rapid and accurate diagnosis of acute cholecystitis with ${ }^{99 \mathrm{~m}} \mathrm{Tc}$-HIDA cholescintigraphy. AfR 1979;132:523-8.

19 Nicholson RW, Hastings DL, Testa HJ, Torrance B. HIDA scanning in gallbladder disease. Br $\mathcal{F}$ Radiol 1980;53:878-82.

20 Stubbs RS, McLoy RF, Blumgart LH. Cholelithiasis and cholecystitis: surgical treatment. Clin Gastroenterol 1983;12:179-201.

21 Shuman WP, Gibbs P, Rudd TG, Malk LA. PIPIDA scintigraphy for cholecystitis: false positives in alcoholism and total parenteral nutrition. $A 7 R$ 1982;138:1-5.

22 Weissmann HS, Frank M, Rosenblatt R, Goldman M, Freeman LM. Cholescintigraphy, ultrasonography and computerized tomography in the evaluation of biliary tract disorders. Semin Nucl Med 1979;9: 22-35.

${ }^{23}$ Matolo NM, Stadalnik RC, McGahan JP. Comparison of ultrasonography, computerized tomography, and radionuclide imaging in the diagnosis of acute and chronic cholecystitis. Am f Surg 1982;144:676-81.

24 Wittenberg J. Computed tomography of the body. N Engl F Med 1983; 309:1160-5.

\section{Ethical issues in prenatal diagnosis}

The techniques of early prenatal diagnosis, recently expanded and refined, were well documented late last year in the British Medical Bulletin. ${ }^{1}$ Current methods include screening programmes of at risk groups by estimating maternal serum $\alpha$ fetoprotein concentrations, ultrasound (including real time scanning), amniocentesis, and fetoscopy with or without fetal tissue and blood sampling. The new technique of chorion biopsy is of particular importance since this may be carried out in the first trimester, thus opening the way for early diagnosis and much earlier termination of pregnancy than is possible with other methods.

Such advances have obvious beneficial results. They improve the quantity and quality of information available to both doctors and parents; they alleviate anxiety in "at risk" pregnancies; and they make possible an increasingly accurate policy of selective abortion for congenital abnormalities, avoiding unnecessary terminations. Not everyone will greet such developments with unqualified acclaim. We may identify four interrelated issues of ethical controversy: the moral justification of selective abortion; the rights of parents against the rights of society in regard to decisions about the continuation or termination of a pregnancy; problems of consent and duress in relation to prenatal screening programmes; and questions of risk and benefit inherent in the development of new techniques.

The Abortion Act of 1967 legalised termination of pregnancy on the basis of predicted abnormalities provided that such abnormalities would be a serious handicap to the child if born. No definition of "serious" was offered, but the Act mentioned both mental and physical abnormalities, and in its other clauses it also allowed termination on the basis of risk to the mental health of the pregnant woman or to other children in her family. Thus the legislation appears to support 